\title{
The influence of principal leadership style, infrastructure, and work climate on teachers' performance
}

\author{
Wulan Gontina ${ }^{1}$, Happy Fitria ${ }^{2}$, Alfroki Martha ${ }^{2}$ \\ ${ }^{1}$ Sekolah Menengah Atas Negeri 1 Sembawa Banyuasin, Indonesia \\ ${ }^{2}$ Universitas PGRI Palembang, Indonesia
}

\section{Article Info \\ Article history: \\ Received Jul $12^{\text {th }}, 2021$ \\ Revised Aug $15^{\text {th }}, 2021$ \\ Accepted Aug 30 $0^{\text {th }}, 2021$ \\ Keyword: \\ Principal leadership style \\ Infrastructure \\ Work climate \\ Teachers' performance}

\begin{abstract}
The aim of this study is to determine the effect of the leadership style, infrastructure, and work climate of the principal on teachers' performance. With a descriptive approach, this approach involves quantitative methods. 105 participants consisted of the researh population. There were 79 people in the research sample. In this research, the sampling technique is Simple Random Sampling. The technique of using a questionnaire was used to gather data. Using a Likert Scale to weigh values. Validity, reliability, descriptive analysis, inferential analysis (prerequisite test and classical assumption test), multiple linear regression analysis, hypothesis analysis ( $t$ test and $F$ test) and determination coefficient analysis were used to analyze the results. The findings showed that the leadership style of the principal, infrastructure advice, and work climate had a substantial influence on teachers' performance of SMP Negeri in the Sembawa District partially and simultaneously.
\end{abstract}

(C) 2021 The Authors. Published by IICET

This is an open access article under the CC BY-NC-SA license (https://creativecommons.org/licenses/by-nc-sa/4.0

\section{Corresponding Author:}

Gontina, W.,

Sekolah Menengah Atas Negeri 1 Sembawa Banyuasin, Indonesia

Email: wulangontina5@gmail.com

\section{Introduction}

Education is one of the strategic sectors in enhancing national development, because with education, human resources can be educated to become the next generation who are superior in their fields. Quality and professional human resources are obtained from the implementation of education starting from elementary school to tertiary level [1]. This is in accordance with the Law of the Republic of Indonesia Number 20 of 2003 which states that based on the vision and mission of national education, national education functions to develop capabilities and shape the character and civilization of a nation with dignity in order to educate the nation's life, aiming to develop the potential of students. in order to become human beings who believe and fear the Almighty God, have noble character, are healthy, knowledgeable, capable, creative, independent and become democratic and responsible citizens. In essence, teacher performance is the behavior produced by a teacher in carrying out his duties as an educator and teacher when teaching in a class according to predetermined criteria so that he can become a professional teacher while professional teachers themselves are qualified, competent, and desired teachers. to bring in learning achievement and be able to influence the learning process of students which in turn will result in better student achievement [2].

Basically, teachers have a high enough potential to create and improve performance, therefore there is a need for continuous and continuous coaching with directed and systematic programs for teachers and school personnel. 
The principal has a very important role in coordinating, so it requires a high level of coordination. Therefore, successful school principals who are able to realize school goals, as well as the goals of individuals in the school environment, must understand and master the role of the organization and the cooperative relationship between individuals [3]. Teachers greatly affect the quality of learning in schools, because teachers have a fairly dominant role in the learning process in schools and teachers are responsible for the learning process in the classroom and it can even be said that teachers are providers of education in schools [4]. Teachers as educational staff are required to have four competencies as professional teachers, namely personality competence, professional competence, personal competence and social competence [5].

The successes and failures of subordinates are a direct reflection of the success or failure of a leader. The principal is one of the driving forces for the school to realize the vision, mission, goals and objectives of the school through program programs that are implemented in a planned and gradual manner [6]. [7] states that the principal's leadership style is the leadership style of a school principal that shows directly or indirectly about a principal's belief in the abilities of his subordinates, meaning that the principal's leadership style is the result of a combination of the philosophy, skills, traits, attitudes applied a leader when he tries to influence the performance of his subordinates. [8] suggests four leadership styles including the principal's leadership style, namely: authoritarian style, pseudo-democratic, Laissez-faire style (free style) and democratic style. According to Soetopo and Soemanto, leadership styles are divided into 4, namely: authoritarianstyle, laissez-fairestyle, democratic style andstyle pseudo-democratic [9].

Another factor that affects teacher performance is school facilities and infrastructure. Educational infrastructure is a very important factor in increasing the efficiency of learning and learning [10]. [11] means are direct tools to achieve educational goals. Educational facilities include school buildings and furniture, learning tools consisting of bookkeeping, teaching aids and laboratories, as well as educational media which can be grouped into audiovisuals using skilled tools. Meanwhile, infrastructure is an indirect tool to achieve educational goals. [11] educational infrastructure is all basic equipment that indirectly supports the implementation of the educational process in schools and educational facilities are all equipment, materials and furniture that are directly used in the teaching and learning process.

Apart from the principal's leadership style and infrastructure, another factor that can improve teacher performance is the work climate in the school environment. [12] the school work climate that is always expected by all school members is a condition and school environment that is very safe, comfortable, peaceful and pleasant for teaching and learning activities that will awaken and strengthen the performance of educational personnel which will affect the successful achievement of implementation in realizing goals., vision and mission of the school. According to Pines, quoted [13], the work climate of an organization can be measured through four dimensions, namely: psychological dimensions, structural dimensions, social dimensions and bureaucratic dimensions.

Based on previous research [12]which examined the influence of the principal's leadership style and school work climate on teacher performance. Based on the results of the study, it was found that the principal leadership style variable and school work climate had a positive effect on teacher performance. This implies that the better the leadership style of the principal and the school work climate results in increased teacher performance with the $t$ value of the principal's leadership style variable is 5.352 and is greater than the table 2.011 and the $t$ value of the work climate variable is 5.791 and is greater than $t$ table 2,011 .

\section{Method}

This research was conducted at SMP Negeri 1 Sembawa District, Banyuasin Regency, namely SMP Negeri 1 Sembawa and SMP Negeri 2 Sembawa, Banyuasin Regency from August to October 2020. The method used in this research is quantitative research method with a descriptive approach. This study aims to determine the influence of the four variables, namely independent or independent variables, namely the

Principal Leadership Style (X1) School Infrastructure (X2), Work Climate (X3) and the dependent or dependent variable, namely Teacher Performance (Y). The population in this study were all SMP Negeri 1 Sembawa teachers and 105 SMP Negeri 2 Sembawa teachers. The number of samples of this study were 79 people, this number became the research respondents. Furthermore, the sampling technique was simple random sampling, namely by drawing the research sample. [14], random sampling can be done by random, computer, or by lottery.

Data collection is a way to obtain data needed in research activities. The data collection was carried out by the researcher, namely the first researcher conducted a pre-research with expert testing and continued with the trial phase. At this trial stage the researchers distributed a questionnaire or research instrument. Instrument testing was 
carried out on respondents outside the sample. After obtaining valid and reliable instrument items, retesting is carried out which only involves the instrument items that have previously been tested to obtain data that will later be tested to determine the results of the research. For data collection using primary data sources and secondary data sources. Primary data sources are obtained by asking respondents, namely teachers to fill out questionnaires or questionnaires that are distributed. According to [14], a questionnaire is an efficient data collection technique that can be in the form of closed and open questions or statements, can be given to respondents directly or sent via post or the internet. The questionnaire used in this research is a closed questionnaire with a Likert scale, namely a questionnaire that has provided a statement so that the respondent only has to fill in the answers by putting a checklist in the column with the alternative answers available. Secondary data sources in this study are profiles of SMP Negeri 1 Sembawa and SMP Negeri 2 Sembawa, research documentation in the form of photos of activities during coaching meetings or hospitality activities which can be seen on the appendix page.

\section{Results and Discussion}

The instrument testing in this study was conducted in schools that were not the research samples. The validity test uses the corrected item-total correlation with SPSS version 25. A question item is said to be valid if the calculated r-value $>$ r-table. With a critical number of table correlation of $5 \%$. In this study, all question items were declared valid with all $\mathrm{r}$ count values of teacher performance variables, principal leadership style, infrastructure and work climate greater than $r$ table $(r$ table $=0.468$ ). In addition, an instrument is reliable as a means of collecting data if it gives the same measure of a symptom at different times. Reliability testing were analyzed with SPSS version 25 with coefficient of reliability(reliability) of $5 \%$. The reliability test of the principal's leadership style instrument obtained avalue Cronbach Alpha of 0.960 , rcount $=0.960>\mathrm{r}$ table $=0.468$, for infrastructure facilities it was obtained at $0.995, \mathrm{r}$ count $=0.995>\mathrm{r}$ table $=0.468$, for the working climate the value was obtained. equal to $0.992>\mathrm{r}$ table $=0.468$ while the teacher performance $\mathrm{r}$ count $=0.997>\mathrm{r}$ table $=0.468$. So it can be concluded that the three variables are declared reliable. Furthermore, the questionnaire score data for 79 respondents were processed to obtain the desired data, then the data were described for each variable.

Table $1<$ Results of the Descriptive Statistical Analysis of Research Variables $>$

\begin{tabular}{lccccc}
\hline & N & Min & Max & Mean & Std. Deviation \\
Teacher Performance & 79 & 66 & 75 & 70,99 & 2,725 \\
Principal Leadersip Style & 79 & 85 & 95 & 90,85 & 2,466 \\
Infrastructure & 79 & 59 & 80 & 71,59 & 5,422 \\
Work Climate & 79 & 39 & 50 & 44,66 & 2,731 \\
\hline
\end{tabular}

Normality Results calculated using SPSS version 25 was obtained variables Style Principal Leadership (X1), Infrastructure (X2), Work Climate (X3) and Teacher Performance (Y) it can be concluded that Teacher Performance data $(\mathrm{Y})$ has $0.111>0.05$, thus data is normally distributed, style Principal leadership (X1) has a significant $0.135>0.05$, thus data is normally distributed, infrastructure (X2) has a significant $0.436>0.05$, thus data is normally distributed, Work Climate (X3) has a significant $0.188>0.05$, thus the data is normally distributed.

The significance value obtained from the linearity test shows that between the Principal Leadership Style variable and teacher performance is 0.127 . Because the value is $0.127>0.05$, the relationship between the two is said to be linear. In the linearity test between the infrastructure facilities and teacher performance variables is $0.211>0.05$, the relationship between the two is said to be linear. In the work climate variable with teacher performance with a value of $0.965>0.05$, the relationship between the two is said to be linear. For the autocorrelation test, the Durbin Watson (DW) value is 2.208 , this shows that the value is between -2 to +2 , so there is no autocorrelation. The results of heteroscedasticity testing using the Scatterplot chart test can be seen in Figure 1.

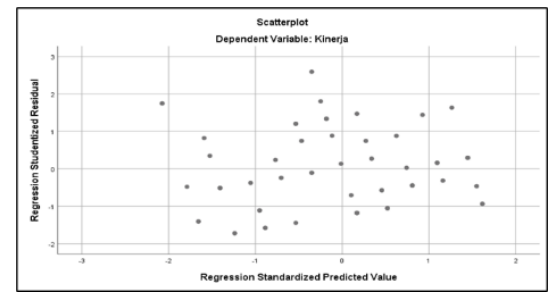

Figure $1<$ Scatterplot Graph> 
Based on Figure 1, it can be seen that the dots spread out randomly with no clear pattern, and the dots spread above and below the number 0 on the $\mathrm{Y}$ axis, so there is no heteroscedasticity. Furthermore, the results of the calculation of the multicollinearity test using SPSS Version 25 obtained the tolerance value for the principal's leadership style variable (X1) is $0.954>0.10$ and the VIF value is $1.048<10.00$, which means that there is no multicollinearity, the tolerance value for the infrastructure facilities variable (X2) is $0.953>0.10$ and the VIF value is $1.049<10.00$, which means that there is no multicollinearity and the tolerance value for the Working Climate variable (X3) is $0.981>0.10$ and the VIF value is $1.020<10.00$ which means that there is no multicollinearity.

Table 2<Multiple Linear Regression Test $>$

\begin{tabular}{|c|c|c|c|c|c|c|}
\hline \multirow{2}{*}{\multicolumn{2}{|c|}{ Model }} & \multicolumn{2}{|c|}{$\begin{array}{l}\text { Unstandardized } \\
\text { Coefficients }\end{array}$} & \multirow{3}{*}{$\begin{array}{l}\text { Standardized } \\
\text { Coefficients } \\
\text { Beta }\end{array}$} & \multirow{3}{*}{$\begin{array}{l}\mathbf{t} \\
3.117\end{array}$} & \multirow{3}{*}{$\begin{array}{l}\text { Sig. } \\
0.003\end{array}$} \\
\hline & & \multirow{2}{*}{ B 17.141} & \multirow{2}{*}{$\begin{array}{l}\text { Std. Error } \\
5.499\end{array}$} & & & \\
\hline 1 & (Constant) & & & & & \\
\hline & Leadership Style & 0.317 & 0.105 & 0.328 & 3.007 & 0.004 \\
\hline & Infrastructure & 0.178 & 0.052 & 0.354 & 3.444 & 0.001 \\
\hline & Work Climate & 0.278 & 0.092 & 0.314 & 3.023 & 0.003 \\
\hline
\end{tabular}

According to Suharsaputra in [15], multiple linear regression is a regression with the number of independent variables more than one so that the equation becomes:

$$
\begin{gathered}
Y=a+b 1 X 1+b 2 X 2+\cdots \ldots b n X n \\
Y=a+b 1 X 1+b 2 X 2+b 3 X 3 \\
Y=17,141+0,317 X 1+0,178 X 2+0,278 X 3
\end{gathered}
$$

\section{Hypothesis Testing}

1. Partial Testing

Test uses the t test through the SPSS version 25 program to test whether each independent variable has a significant effect on the dependent variable partially. While the value of $t$ table is obtained from the formula $t$ table $=(\alpha / 2, n k)$ where $n$ is the number of respondents and $\mathrm{k}$ is the number of research variables. so that $\mathrm{t}$ table $=(0.025 ; 79-4)=(0.025 ; 75)=1.99210$.

Hypothesis 1: The $t$ value of the principal's leadership style of 3.007 is greater than the table value of 1.99210 and the significance value (sig) of 0.004 is less than 0.05 , meaning that Ho is rejected and Ha is accepted, meaning that the leadership style of the principal is influential. significant to teacher performance.

Hypothesis 2: The $t$ value of the infrastructure facilities is 3.444, greater than the table value of 1.99210 and the significance value (sig) of 0.001 is less than 0.05 . So it can be concluded that Ho is rejected and Ha is accepted, meaning that infrastructure has a significant effect on teacher performance.

Hypothesis 3: The $t$ value of the work climate is 3.023 smaller than the table value of 1.99210 and the significance value (sig) of 0.003 is less than 0.05 . So it can be concluded that Ho is rejected and Ha is accepted, meaning that the work climate has a significant effect on teacher performance.

2. Simultaneous Test

Table $3<$ Simultaneous Hypothesis Testing>

\begin{tabular}{llccccc}
\hline Model & Sum of Squares & df & Mean Square & F & Sig. \\
1 & Regression & 568.053 & 3 & 189.351 & 1298.763 & $.000^{\mathrm{b}}$ \\
& Residual & 10.934 & 75 & 0.146 & & \\
\hline & Total & $\mathbf{5 7 8 . 9 8 7}$ & $\mathbf{7 8}$ & & & \\
\hline
\end{tabular}

In table 3, it is obtained that the Fcount is 1298.763 and the result is a significance of 0.000 . Ftable can be seen in the statistical table at a significance level of 0.05 with df 2 (nk-1) or (79-4-1) = 74 (where $n$ is the amount of data and $\mathrm{k}$ is the number of independent variables), the results obtained for Ftable are 2.73. So it can be concluded that if Fcount $>$ Ftable $(1298.763>2.73)$ it can be concluded that H0 is accepted, so Ha is rejected, then the leadership style, infrastructure and work climate simultaneously have a significant effect on the performance of SMP Negeri teachers in Sembawa District. 
Table $4<$ The Determinant Coefficient of Hypothesis>

\begin{tabular}{lllllll}
\hline Model & $\begin{array}{l}\text { Sum } \\
\text { Squares }\end{array}$ & of & df & $\begin{array}{l}\text { Mean } \\
\text { Square }\end{array}$ & F & Sig. \\
\hline $\mathbf{1}$ & Regression & 568.053 & 3 & 189.351 & 1298.763 & $.000^{\mathrm{b}}$ \\
& Residual & 10.934 & 75 & 0.146 & & \\
& Total & 578.987 & 78 & & & \\
\hline
\end{tabular}

Coefficient of determination (R2)aims to test how much influence the independent variable on the dependent variable. If this test is done through SPSS Version 25, the coefficient of determination can be seen in the output Model of Summary Rcolumn Square when calculating Regression [15]. The results of the calculation of the coefficient of determination in table 4 can be interpreted that the influence of the principal's leadership style, infrastructure and work climate together on the performance of SMP Negeri teachers in Sembawa District $98.1 \%$, the remaining $1.9 \%$ is influenced by other factors that are not mentioned. variables in this study.

\section{Discussion}

The results of this study are in line with previous research conducted [12] entitled which examines the influence of the principal's leadership style and school work climate on teacher performance. Based on the results of the study, it was found that the variables of the principal's leadership style and school work climate had a positive effect on teacher performance. This implies that the better the leadership style of the principal and the school work climate results in increased teacher performance with the t value of the principal's leadership style variable is 5.352 and is greater than the $\mathrm{t}$ table 2.011 and the $\mathrm{t}$ value of the work climate variable is 5.791 and is greater than $\mathrm{t}$ table 2,011

1. The Influence of the Principals' Leadership style on teacher performance

Leading is the art of influencing others as subordinates. A leader is a person who inspires, persuades, influences and motivates others. Leadership as the ability to influence or encourage a person or group of people to work voluntarily to achieve certain goals or objectives in certain situations, so that the leadership of the principal is required not only to be able to lead or manage schools, but also to be able to create a conducive atmosphere in the work climate (climate). -maker) so as to improve teacher performance. The results showed that there was a significant effect of the principal's leadership style on teacher performance. This is indicated by the $t$ value of the principal's leadership style of 3.007, greater than the t table value of 1.99210 and the significant value (sig) of 0.004 less than 0.05 . With the assumption that Ho is rejected and Ha is accepted. Based on the description above, it can be concluded that the principal's leadership style has an effect on the performance of SMP Negeri teachers in Sembawa District.

2. The effect of Infrastructure on teacher performance.

According to Nurabadi (2014), one aspect that should receive the main attention of every education administrator is educational facilities and infrastructure. Educational infrastructure is one of the determining factors for the success of education. The results of hypothesis testing obtained that the $t$ value of the infrastructure facilities is 3.444, greater than the $t$ table value of 1.99210 and the significance value (sig) of 0.001 is less than 0.05 . With the assumption that $\mathrm{Ho}$ is rejected and $\mathrm{Ha}$ is accepted, it means that the infrastructure has a significant effect on the performance of the teachers of the State Junior High School in Sembawa District. Therefore, the research results can be used as a guide for principals, teachers, and schools that infrastructure has an influence on teacher performance, both direct and indirect. With the complete and supportive infrastructure, it will be able to improve teacher performance.

3. The effect of the work climate on teacher performance.

[12] the school work climate that is always expected by all school members is a condition and a school environment that is very safe, comfortable, peaceful and pleasant for teaching and learning activities that will awaken and strengthen the performance of educational personnel that will affect the successful achievement of implementation in realizing the goals, vision and mission of the school. The results of this study indicate that there is a positive influence between the work climate and the performance of SMP Negeri teachers in Sembawa District. Based on the calculation, the $t$ value of the work climate is 3.023 , greater than the $t$ table value of 1.99210 and the significance value (sig) of 0.003 is less than 0.05 . From these results it can be assumed that $\mathrm{Ho}$ is rejected and $\mathrm{Ha}$ is accepted. This means that the work climate has a significant effect on teacher performance. 
4. The effect of the princpals' Leadership Style, Infrastructure and Work Climate on teacher performance. The results showed that there was a positive and significant relationship between the principal's leadership style, infrastructure and work climate on the performance of teachers of SMP Negeri in Sembawa District. This is evidenced by the value of the hypothesis testing results obtained by the Fcount value of 1298.763 , greater than $\mathrm{F}$ table 2.73 with a significance value of 0.000 less than 0.05 . So it can be concluded that Ho is accepted, so that $\mathrm{Ha}$ is rejected, meaning that the principal's leadership style, infrastructure and work climate affect teacher performance. The magnitude of the influence of the principal's leadership style, infrastructure and work climate on the performance of SMP Negeri teachers in Sembawa District was $98.1 \%$ and the remaining $1.9 \%$ was influenced by other factors not included in the variables in this study.

\section{Conclusions}

Based on the results of the research and discussion, it can be concluded that there is an influence of the principal's leadership style, infrastructure and work climate partially on the performance of SMP Negeri teachers in Sembawa District. There is an influence of the principal's leadership style, infrastructure and work climate on the performance of teachers together at SMP Negeri in Sembawa District.

\section{References}

Ahmad, S. (2016). Ketahanmalangan Kepemimpinan Kepala Sekolah : Salah satu faktor penentu keberhasilan kepala sekolah. Yogyakarta: Deepublish.

Ali, M. (2016). Pengaruh Kepemimpinan Partisipatif Kepala Sekolah Dan Iklim Kerja Organisasi Terhadap Kinerja Guru SMP Negeri Di Kota Mataram. Jurnal Administrasi Pendidikan, 1(2), 163-173. doi:https://doi.org/10.29303/jipp.v1i2.12

Aprida, Y., Fitria, H., \& Nurkhalis, N. (2020). Pengaruh supervisi kepala sekolah dan motivasi kerja guru terhadap kinerja guru. Journal of Education Research, 1(2), 160-164.

Damayani, T., Arafat, Y., \& Eddy, S. (2020). Pengaruh Kepemimpinan Kepala Sekolah dan Motivasi Kerja terhadap Kinerja. Journal of Innovation in Teaching and Instructional Media, 1(1), 46-57.

Darmawan, A. (2019). Pengaruh Gaya Kepemimpinan Kepala Sekolah dan Budaya Sekolah Terhadap Kinerja Guru (Studi Pada SMK Rumpun Pariwisata di Kota Tanggerang). Mandiri, 3(2), 244-256. doi:https://doi.org/10.33753/mandiri.v3i2.85

Fitria, H., \& Martha, A. (2020). Manajemen Kepemimpinan Kepala Sekolah dalam Meningkatkan Kinerja Guru Honorer. Journal of Innovation in Teaching and Instructional Media, 1(1), 85-89.

Kesumawati, N., \& Aridanu, I. (2018). Statistik Parametrik Penelitian Pendidikan. Palembang: Noer Fikri

Murtiningsih, \& Lian, B. (2017). Proses Pengambilan Keputusan Kepala Sekolah Terhadap Peningkatan Kinerja Guru SMP. Jurnal Manajemen, Kepemimpinan, dan Supervisi Pendidikan (JMKSP), 2(1), 87-96.

Mawaddah, M., Harapan, E., \& Kesumawati, N. (2020). Pengaruh kepemimpinan kepala sekolah dan ketersediaan sarana dan prasarana terhadap kepuasan kerja guru. JMKSP (Jurnal Manajemen, Kepemimpinan, dan Supervisi Pendidikan), 6(1), 100-111.

Nurabadi, A. (2014). Manajemen Sarana dan Prasarana Pendidikan (T. Triwiyanto Ed. 1 ed.). Malang: Kementerian Pendidikan Kebudayaan Universitas Negeri Malang Fakultas Ilmu Pendidikan Jurusan Administrasi Pendidikan.

Nursam. (2020). Gaya Kepemimpinan Kepala Sekolah Dalam Mengembangkan Kinerja Pendidik. Jurnal Kelola: Journal of Islamic Education Management, 5(1),27-38. doi:http://ejournal.iainpalopo.ac.id/index.php/kelola

Rahmat, A., \& Kadir, S. (2017). Kepemimpinan Pendidikan dan Budaya Mutu. Yogyakarta: Zahir Publishing.

Sutianingsih. (2016). Pengaruh Gaya Kepemimpinan Kepala Sekolah dan Iklim Kerja Sekolah Terhadap Kinerja Guru. JIMAT (Jurnal Ilmu Manajemen dan Akutansi Terapan), 7(2), 115-131.

Sugiyono. (2019). Metode Peneltian Kuantitatif, Kualitatif, dan R\&D (Sutopo Ed. 2 ed.). Bandung: Alfabeta.

Zulfiter, Z., Fitria, H., \& Nurkhalis, N. (2020). Pengaruh Gaya Kepemimpinan Kepala Sekolah dan Motivasi Kerja Terhadap Kinerja Guru. ISEJ: Indonesian Science Education Journal, 1(3), 269-277. 